\title{
Dissociation of Hyperglycaemia and Obesity in Mice Fed High Fat Diets*
}

\author{
M.W. Kramer, D.F. Liberman, J.S. Solldner, and R.E. GLeason \\ Suffolk University, the Elliott P. Joslin Research Laboratory in the Department of Medicine, Harvard Medical School \\ and the Peter Bent Brigham Hospital, and the Joslin Diabetes Foundation Inc., Boston, Massachusetts, U.S.A.
}

\author{
Received: February 10, 1969
}

Summary. Three groups of weanling male SwissHauschka mice were maintained, respectively, on diets containing 4.5 (Diet I), 11.0 (Diet II), and 12.0 (Diet III) percent fat for seven months. The fat source for Diet I was mixed; for Diet II, corn oil; and for Diet III, hydrogenated vegetable oil (Crisco). The animals on Diet II showed significantly higher total and percent extractable lipid per mouse than those fed Diet I or III. However, the animals on Diet II and III had significantly higher blood glucose levels than those on Diet I. These results suggest that certain types of high fat and/or high caloric diets may induce hyperglycaemia in mice without production of obesity.

Dissociation de l'hyperglycémie et de l'obésité chez des souris soumises à un régime riche en matières grasses

Résumé. Trois groupes de jeunes souris mâles SwissHauschka ont été maintenues respectivement à des régimes contenant 4.5 pour cent de matières grasses (Régime I), $11.0 \%$ (Régime II) et $12.0 \%$ (Régime III) pendant 7 mois. Pour le régime I les matières grasses étaient constituées par un mélange; pour le rógime II, elles étaient constituées par de l'huile de céréales; et pour le régime III elles étaient constituées par do I'huilo végétale hydrogénée (Crisco). Les animaux du régime II ont montré, par souris, un total et un pourcentage de lipides extractibles significativement plus élevés que ceux nourris suivant le régime I et III. Cependant les animaux du régime II et III avaient des taux de glycémie significativement plus élevés que ceux du régime I. Ces résultats suggèrent que certains types de régimes riches en matières grasses et/ou hautement caloriques peuvent produire l'hyperglycémie chez les souris sans provoquer l'obésité.

Dissoziation von Blutzuckererhöhung und Fettsucht bei fettreich ermährten Mäusen

Zusammenfassung. Drei Gruppen von 3 Wochen alten ,Swiss-Hauschka"-Mäusen, männlichen Geschlechts wurden 7 Monate lang mit verschiedenen Diäten ernährt, deren Fettgehalt 4.5 (Diät I), 11.0 (Diät II), und 12.0 (Diät III) Prozent betrug. Diät I enthielt gemischtes Fett; Diät II Mais-ÖI und Diät III hydrogenisiertes Pflanzenöl (Crisco). Die mit Diät II gefütterten Tiere zeigten eine signifikante Vermehrung sowohl der gesamten, als auch der in Prozenten ausgedrückten Menge der extrahierbaren Lipide pro Maus, verglichen mit den mit Diät I und III ernährten. Tiere der Diät-Gruppe II und III wiederum hatten signifikant höhere Blutglucosekonzentrationen als die der Diät-Gruppe I. Es wird vermutet, daß verschiedene Arten von fett. und/oder kalorienreicher Nahrung bei Mäusen Hyperglykämie verursachen, ohne jedoch zur Fettsucht zu führen.

Key-words: Mice, hyperglycaemia, body lipid content, diet, obesity.
Several types of genetically obese mice strains have been studied extensively with regard to the nature, and physiologic and endocrinologic effects of their obesity $[2,8]$. Another type of obesity which is also of interest is the so-called nutritional obesity, wherein the adiposity appears to be a function of the caloric content of the diet. The caloric level of such diets is usually increased by increasing the proportion of fat.

The amount of fat in the diet has been shown to influence body weight, blood glucose and immunoreactive insulin levels in mice [6]. High fat diets have also been reported to decrease glucose tolerance in both mice and rats $[3,1]$. In addition to the amount of fat, the source of dietary fat has been shown to be related to hyperglycaemia [1]. The purpose of this study was to compare body weights, blood glucose levels and total body lipid content in mice fed three different diets.

\section{Materials and Methods}

A total of 47 commercial strain, random-bred weanling male mice ${ }^{\mathbf{1}}$ from a cross between the Hauschka and

* Supported by U.S.P.H.S. grants AM-09748-03, AM-11959-01 and the John A. Hartford Foundation Ine., New York City, New York.

1 Charles River Breeding Laboratories, Wilmington, Massachusetts.
Mirand-Roswell Park Memorial Institute inbred lines were used in this study. These mice were separated at random into three diet groups as follows: Group I $(n=14)$, Purina Laboratory $\mathrm{Chow}^{2}$; Group II $(n=13)$, Old Guilford Breeder Pellets ${ }^{3}$; and Group III $(n=20)$, fat-deficient test diet ${ }^{4}$ with 12 percent Crisco added. The three diets are characterized in Table 1.

All animals were maintained under standard laboratory conditions. Food and water were available ad libitum

After seven months on these diets, all animals were weighed, and blood samples for glucose levels in all were obtained during a two hour period following a $12 \mathrm{~h}$ fast. After killing by decapitation, the carcasses were immediately frozen until the time total body lipid measurements were made. All groups were studied simultaneously to exclude seasonal influences.

Glucose levels were determined by the AutoAnalyzer (Technicon Instruments Corporation, Chauncey, New York) using Technicon method N-9a [7].

Total body lipid was determined as follows. After decapitation and the collection of blood samples for

Rualston Purina Company, St. Louis, Missouri.

3 The Emory Morse Company, Guilford, Connecticut.

4 Nutritional Biochemicals, Inc., Cleveland, Ohio. 
analysis, the head and body were weighed, then wrapped in aluminum foil and kept at $-20^{\circ} \mathrm{C}$. Carcasses, selected at random while frozen, were placed in a high speed blender and homogenized for 3 min after addition of $200 \mathrm{ml}$ of distilled water. The total volume of homogenate was measured and a $50 \mathrm{ml}$ aliquot was lyophilized, then transferred to a $50 \mathrm{ml}$ teflon capped tube. identical, the mean total extractable lipid or percent extractable lipid per mouse of Group II was significantly higher than in Group I or Group III $(p<0.001)$. The primary fat source in II was corn oil, whereas in III the diet included 12 percent Crisco, which was primarily hydrogenated soybean and cottonseed oil. Group I diet had a heterogeneous fat source consisting

Table 1. Composition of Diets

\begin{tabular}{|c|c|c|c|c|c|c|}
\hline \multirow{2}{*}{$\begin{array}{l}\text { Diet } \\
\text { Group }\end{array}$} & \multirow{2}{*}{$\begin{array}{l}\text { Calories } \\
\text { per } 100 \mathrm{~g}\end{array}$} & \multicolumn{3}{|c|}{ Percent by Weight } & \multirow{2}{*}{$\begin{array}{l}\text { Fat } \\
\text { Sources }\end{array}$} & \multirow{2}{*}{$\begin{array}{l}\text { Diet } \\
\text { Form }\end{array}$} \\
\hline & & Protein & Carbohydrate & Fat & & \\
\hline$I$ & 374 & 23 & 51 & 4.5 & $\begin{array}{l}\text { Animal Fat } \\
+ \text { Corn oil } \\
+ \text { others }\end{array}$ & $\overline{\text { Pellets }}$ \\
\hline II & 419 & 19 & 52 & 11.0 & Corn oil & Pellets \\
\hline III & 452 & 27 & 59 & 12.0 & $\begin{array}{l}\text { Crisco } \\
\text { (hydro- } \\
\text { genated } \\
\text { soybean and } \\
\text { cottonseed } \\
\text { oil) }\end{array}$ & $\begin{array}{l}\text { Dense } \\
\text { Powder }\end{array}$ \\
\hline
\end{tabular}

The tube was filled with a 2:1 chloroform:methanol mixture $(v / v)$ of lipid-extracting fluid and shaken overnight. The extracting fluid and six washes were transferred to a tared beaker, and remained in a room tem. perature hood $\left(22^{\circ} \mathrm{C}\right)$ until constant weight was achieved. Total extractable lipid was calculated by making the appropriate allowance for the fraction of whole mouse in the aliquot.

\section{Results and Discussion}

The diets used in Groups I and II have been previously compared in Swiss mice [6] with regard to body weights and blood glucose levels. In this study a third diet with a fat level equivalent to that fed in Group II, but from a different source, was included.

The results are summarized in Table 2. The mean blood glucose levels in Group II and Group III were of 0.9 percent animal fat (pork), 1.05 percent corn oil, and the remaining 2.5 percent from a variety of other ingredients $[10]$.

These results suggest that the amount of total body lipid in mice is not related to the amount of fat or to the caloric content of the diet. The group fed the high fat, high caloric diet III did not appear to differ from the low fat, low caloric diet I with regard to body weight or extractable lipid. However, the form of diet III, a dense powder, may not have been as palatable as the pellet diet $I$, and as a consequence, less food may have been consumed. The blood glucose measurements obtained on Group III were nearly identical to those in Group II suggesting that the effects of the two high fat, high caloric diets contributed equally to a blood glucose elevation, despite significant differences in total body weight and lipid content.

Table 2. Mean Body Weight, Blood Glucose, Weight and Percent Lipid, and Fat-Free Weight for Mice Fed Diets Differing in Type and Amount of Fat

\begin{tabular}{cllllll}
\hline Group (n) & $\begin{array}{l}\text { Diet Fat } \\
(\%)\end{array}$ & $\begin{array}{l}\text { Mean Body } \\
\text { Weight } \\
(\mathrm{g})\end{array}$ & $\begin{array}{l}\text { Mean Blood } \\
\text { Glucose } \\
(\mathrm{mg} \%)\end{array}$ & $\begin{array}{c}\text { Mean Lipid } \\
(\mathrm{g})\end{array}$ & $\begin{array}{l}\text { Mean Fat- } \\
\text { free Weight } \\
(\mathrm{g})\end{array}$ \\
\hline I (13) & 4.5 & $44.5 \pm 1.6^{\mathrm{a}}$ & $115 \pm 8^{\mathrm{b}}$ & $5.9 \pm 0.8$ & $12.9 \pm \mathbf{1 . 6}$ & $\mathbf{3 8 . 6} \pm 1.4$ \\
\hline II (10) & 11 & $49.0 \pm 1.3$ & $156 \pm \mathbf{1 3}$ & $11.9 \pm 1.3$ & $23.9 \pm 2.4$ & $\mathbf{3 7 . 1} \pm 1.1$ \\
\hline III (14) & 12 & $44.0 \pm 0.8$ & $157 \pm 9$ & $4.8 \pm 0.4$ & $10.8 \pm 0.9$ & $39.2 \pm 0.7$ \\
\hline
\end{tabular}

a S.E.M.

b $n=11$

nearly identical, but both were higher than that in Group I $(p<0.01)$. The mean body weight of the animals in Group II was higher than that for both Group I $(p=0.05)$ and Group III $(p<0.01)$. Although the mean fat-free weights of the groups were nearly
It should be pointed out, however, that Diets II and III had minor differences in protein and carbohydrate content (Table 1), which could have contributed to these differences.

A few other studies have evaluated the effect of 
dietary fat composition and fat type upon total body lipid and/or blood glucose homeostasis in rodents. BARBORIAK and KREHL [1] noted that hyperglycaemia following glucose tolerance testing was more pronounced in groups of rats fed margarine or Crisco diets than in animals receiving lard or butter diets over a nine month period. It was also noted that rats maintained on diets high in corn oil for a six week period showed a decreased glucose tolerance. Similar results were reported by BLOOM and FENTON [3] in mice fed on a $50 \%$ fat diet ( $45 \%$ Crisco and $5 \%$ corn oil) from wearing to eight months of age.

Fat deposition as a function of diet appears to be genetically controlled. FENTON [5] noted that inbred strains $\mathrm{C}_{3} \mathrm{H} / \mathrm{Fn}$ and $\mathrm{A} / \mathrm{Fn}$ were highly susceptible to nutritionally-induced obesity, whereas the I/Fn strain was virtually resistant to obesity, even when maintained on a diet containing $50 \%$ fat. $\mathrm{C}_{57} \mathrm{BL} / \mathrm{Fn}$ were intermediate in their ability to adjust caloric intake to caloric need. BOYLAN and RoBERTs [4] noted significant differences in four out of seven fatty acids studied, with regard to the amount deposited in the tissues of two inbred lines fed the same diet. The percent carcass protein did not differ between lines.

No reports wherein the type of fat in the diet was studied with regard to total body lipid content were found. It appears from the results of this study, however, that this may be an important factor in the development of nutritional obesity in mice.

Evidence in man suggests that obesity associated with an increase in the size of the adipose tissue cell is accompanied by a decreased responsiveness of the tissue to insulin and an impaired glucose tolerance [9]. However, these present studies in mice suggest that certain types of lipid in the diet may induce hyperglycaemia without the concomitant induction of obes. ity.

\section{References}

1. Barboriak, J.J., and W.A. KrEHL. Effect of dietary fats on glucose tolerance and alloxan diabetes. Amer. J. Nutr. 150, $639-642$ (1965).

2. BAtT, R.A.L., and G.A. HaRrrson: Features of the "adipose" mouse. Heredity 15, 335 (1960).

3. BŁoom, R.A., and P.F. Fenton: Glucose tolerance in relation to obesity and food intake. Amer. $J$. Physiol. $184,438-440(1956)$

4. Boylan, W.J., and W.K. Roberts: Genetic differences for fatty acids and other body components in mice. J. Agric. Sci. 70, 73-76 (1968).

5. Fenton, P.F.: Growth and fat deposition in the mouse: A definition of obesity. Amer. J. Physiol. 184, $52-54(1956)$.

6. Gleason, R.E., V. Lauris, and J.S. Soemdner. Studies on experimental diabetes in the Wellesley Hybrid mouse III. Dietary effects and similar changes in a commercial Swiss-Hauschka strain. Diabetologia $\mathbf{3}$, $175-178(1967)$.

7. Hofrman, W.S.: A rapid photoelectric method for the determination of glucose in blood and urine. J. biol. Chem. 120, $51-55$ (1937).

8. Mayer, J.: The obese hyperglycemic syndrome of mice as an example of "metabolic" obesity. Amer. J. clin. Nutr. 8, $712-718(1960)$.

9. Salans, L.B., J.L. Knittle, and J. HrRsch: The role of adipose cell size and adipose tissue insulin sensitivity in the carbohydrate intolerance of human obesity. $J$. clin. Invest. 47, 153-165 (1968).

For reprints please contact: Dr. J.S. SoELDNER 170 Pilgrim Road Boston Massachusetts 02215 USA 